\title{
Creating Sustainable Buildings: Structural Design Based on the Criterion of Social Benefits for Building Users
}

\author{
Aleksandra Nenadović * and Jelena Milošević (D) \\ Faculty of Architecture, University of Belgrade, 11120 Belgrade, Serbia; jelena@arh.bg.ac.rs \\ * Correspondence: aleksandra@arh.bg.ac.rs
}

Citation: Nenadović, A.; Milošević, J. Creating Sustainable Buildings: Structural Design Based on the Criterion of Social Benefits for Building Users. Sustainability 2022, 14, 2133. https://doi.org/10.3390/ su14042133

Academic Editors: Oriol Pons-Valladares and Jelena Nikolic

Received: 31 December 2021 Accepted: 11 February 2022 Published: 13 February 2022

Publisher's Note: MDPI stays neutral with regard to jurisdictional claims in published maps and institutional affiliations.

Copyright: (C) 2022 by the authors. Licensee MDPI, Basel, Switzerland. This article is an open access article distributed under the terms and conditions of the Creative Commons Attribution (CC BY) license (https:// creativecommons.org/licenses/by/ $4.0 /)$.

\begin{abstract}
Sustainable building involves reducing negative environmental impacts with a simultaneous increase in life quality. The aim is to optimize building performances while considering all aspects of sustainability: environmental, economic, and social. The building structure determines the building's performances, and it should be designed and evaluated as a subsystem of the building, in line with the objectives of the system-building. This paper investigates structural design based on integrated design objectives within the criterion of social benefits for users throughout the use phase of the building, focusing on protection and safety, aspects of comfort, spatial organization, spatial adaptability, and maintenance. The problem was studied using integrative literature review methodology and system theory. The main findings of the research are a review and critical analysis of the representative literature and the derived conceptual framework for structural design based on the criterion of social benefits for building users, which should support more comprehensive and more efficient decision-making during systemic design and optimization of buildings. The presented integrated literature review indicates the need for the application of a systemic approach to structural design in order to create sustainable buildings.
\end{abstract}

Keywords: sustainable building; integrated design; structural design; social benefits; socially-based criteria for structural design

\section{Introduction}

Sustainable development implies balanced goals of socio-economic development and environmental protection, with a focus on life quality. One of the key strategies for raising the level of sustainability involves reducing negative environmental impacts due to the construction, use, and deconstruction of built capacities, with a simultaneous increase in life quality [1]. Life quality can be interpreted as a relation between an individual and their living environment [2], where the living environment is considered as a complex natural, built, social, cultural, economic, political-administrative, and legal environment, i.e., a unique system of interconnected factors surrounding the human.

This research focuses on the principles of design and evaluation of buildings and their subsystems, considering that design is the underlying problem of human-environment relations and changes in those relations [3], especially bearing in mind that $80 \%$ of the influence of the built capacities on the environment is determined in the design phase [4]. "In many ways, the environmental crisis is a design crisis. It is a consequence of how things are made, buildings are constructed, and landscapes are used." [5] (p. 24).

Spatial design based on the principles of sustainable development requires a qualitatively new approach to building design, i.e., integrated design approach based on a systemic analysis of social, economic, and environmental aspects [6]. The reductionistic approach to building design, based on a limited number of criteria and a linear approach, is replaced by a holistic one, while accepting the complexities of architecture and its systems. The aim is to optimize building performances in line with integrated design objectives. 
Structural design within the integrated building design approach aims to improve the overall performances of a building as a whole. In this process, the load-bearing structure is created on the basis of a series of parameters concerning the building's sustainability. In that context, the notion of optimal behaviour of building structure, i.e., of its optimal performances, is changing [7]. The building structure cannot be understood and thus evaluated without comprehending its relation to a specific function of architectural space.

Some studies have dealt with the topic of sustainable structural design, but they are predominantly related to environmental and economic issues, neglecting social sustainability [8-15]. When it comes to social sustainability, recognized as a fundamental component of sustainability [16], which concerns the creation of "places that promote wellbeing, by understanding what people need from the places" [17] (p. 16), most research to date is related to issues of creating socially sustainable cities, towns, and communities [17-19], i.e., socially sustainable urban development. Some research deals with the social aspect of sustainability in the construction sector [20-24], but a small number look at the subject in an architectural context [25-28]. Given the above, recognizing the importance of a people-centric sustainable built environment, and the lack of research on the subject, the European Commission highlights one of the key objectives to be achieved before 2030, named "Built for and with the people" [29] (p. 50), which concern, among other issues, "achieving specific outcomes for the users in terms of functionality, comfort, convenience, accessibility, health, wellbeing" [29] (p. 14). This objective is closely related to building design, and thus to structural design.

Despite the recognized importance of social sustainability, to the best of the author's knowledge, there is little research related to structural design in this context, especially those who apply a systemic approach and who comprehensively deal with the topic. Having the above in mind, this paper represents the analysis of structural design in line with integrated design objectives within the criteria of social benefits for users through the use phase of the building. The analysis was conducted through an integrative literature review focusing on structural design based on users' needs to review, critique, and synthetize representative publications on the topic in an integrated way, such that a new conceptual framework and perspective can be generated.

The literature review was guided by the research question: According to which principles should building structures be designed in order to achieve social benefits for building users? To answer this question, the research is focused on comprehending the behaviour of building subsystem-building structure directed towards achieving the goal of a system-building - social quality. The primary research aim is to establish the structural design principles in line with integrated design objectives derived from indicators of ecological quality [30], within the criterion of social benefits for users throughout the use phase of the building. Furthermore, the goal is to express these principles through the criteria for integrated design and assessment of the building structures harmonized with the quantitative and qualitative indicators of social benefits to enable their application in architectural practice. The research relates to the issue of the development of sustainable building solutions, but also to the contribution to the methodology of the basic field of research-architecture.

\section{Materials and Methods}

This integrated literature review identifies design strategies and derives and presents a conceptual framework for systemic design and optimization of building structures aimed at improving building performances in line with the integrated design objectives within the criterion of social benefits for building users. An integrative literature review is a distinctive form of research that "reviews, critiques, and synthesizes representative literature on a topic in an integrated way such that new frameworks and perspective on the topic can be generated" [31] (p. 356). This type of literature review was chosen because research focuses the emerging topic, which requires a more creative collection of data, as the goal is not to cover all published works on the topic but rather to combine insights from 
different fields [32]. Another benefit of using this methodology is that it facilitates learning more about the phenomenon and understanding changes in trends of a focused problem, especially when research emerges in different fields [31].

The data analysis part of an integrative literature review is not particularly developed according to a specific standard [33]. However, the general aim is to critically analyse the literature and the main ideas and relationships of an issue [32]. The existing literature on sustainable building and structural design, focusing on social benefits for building users, was searched. The following keywords were used to search the literature: sustainable building, integrated design, structural design, wellbeing, safety and security, thermal comfort, air comfort, acoustic comfort, visual comfort, spatial organization, functional adaptability, and building maintenance. The literature search was conducted in two main databases: Web of Science and Google Scholar. A total of 131 references relevant to the problem was included in the study. Publication formats are journals, conference proceedings, books, chapters in the books, reports, and standards.

The conceptual structuring of the topic was based on system theory as a guiding theory [34], in order to organize the review in a coherent conceptual way [31], and to critically analyse selected data to comprehend the behaviour of a building structure as a subsystem that contributes to the quality of a system - the building as a whole. Moreover, it is a methodological approach that enables scientific shaping of the problem of the whole system, which is a building in the case of this research.

The principles within the applied systemic approach are:

- mutual connection and dependence of a building's subsystem;

- behaviour of subsystem-building structure relating to achieving the goal of systembuilding-social quality;

- $\quad$ observation of the subsystem-building structure within the process of the functioning of the system-building;

- belonging of the system-building itself, as a subsystem, to a higher-level system;

- $\quad$ system-building's interaction with the environment.

In order to build, refine, and organize the body of knowledge, i.e., to explore and reveal the theoretical basis of the said methodological concept of structural design that focuses on how to create buildings as complex systems which successfully perform their function over their life cycle [35], the systems thinking principles are applied. In recent decades, systems thinking, as an investigative methodology related to the conceptualization of functional systems, is replacing the previously dominant approach of reductionism [36]. This way of thinking is aimed at understanding systems, predicting their behaviours, and devising their modifications in order to produce desired effects [37]. It enables a deeper understanding of phenomena through seeing interrelationships rather than things [38]. In systems thinking, functional systems are not only technological systems but are also complex systems of people and technology. They are interdependent on other systems and subsystems, spanning sociological, cultural, political, and economic domains [39]. Systems thinking is also the art of simplifying complexity [40] through considering parts of a system problem while not losing sight of the whole [41].

Figure 1 shows a visual model of systems thinking as a global research methodology applied in this research, along with the research methods in individual research steps:

In order to discover the issues and to search for trends, i.e., to answer the question "What has been happening with the structural design in the context of social sustainability?" a literature review and a critical analysis of bibliographic sources as research methods were applied. These methods were applied to reveal the relevance of the research and establish the research gaps related to structural design in the context of social sustainability. During the search for key causes, i.e., methodological or interpretational constraints that impede progress in the field, the focus question that stimulated future research was developed "According to which principles should building structures be designed in order to achieve social benefits for building users?" The above question arose from the question "Why is the reductionist and prescriptive approach to structural design no longer satisfactory?" 
This question has directed research towards the identification of new goals of structural design, for which critical analysis of bibliographic sources and systems analysis as research methods were applied. These methods were also applied to answer the question "How structural design can be improved in the context of social sustainability?" This involved searching deeper into the problem and developing deeper questions. Searching deeper involved managing complexity through considering parts of a system problem while not losing sight of the whole. In that context, in this research, bounded concerns were considered, related to structural design in the context of safety and security, aspects of comfort, spatial organization, spatial adaptability, and maintenance, ensuring that one of the selected issues is the concern of the system-building as a whole. Identification of design strategies and derivation of structural design criteria, based on the understanding of the goal of the system-building — social quality, implied systems analysis and systems synthesis as research methods.

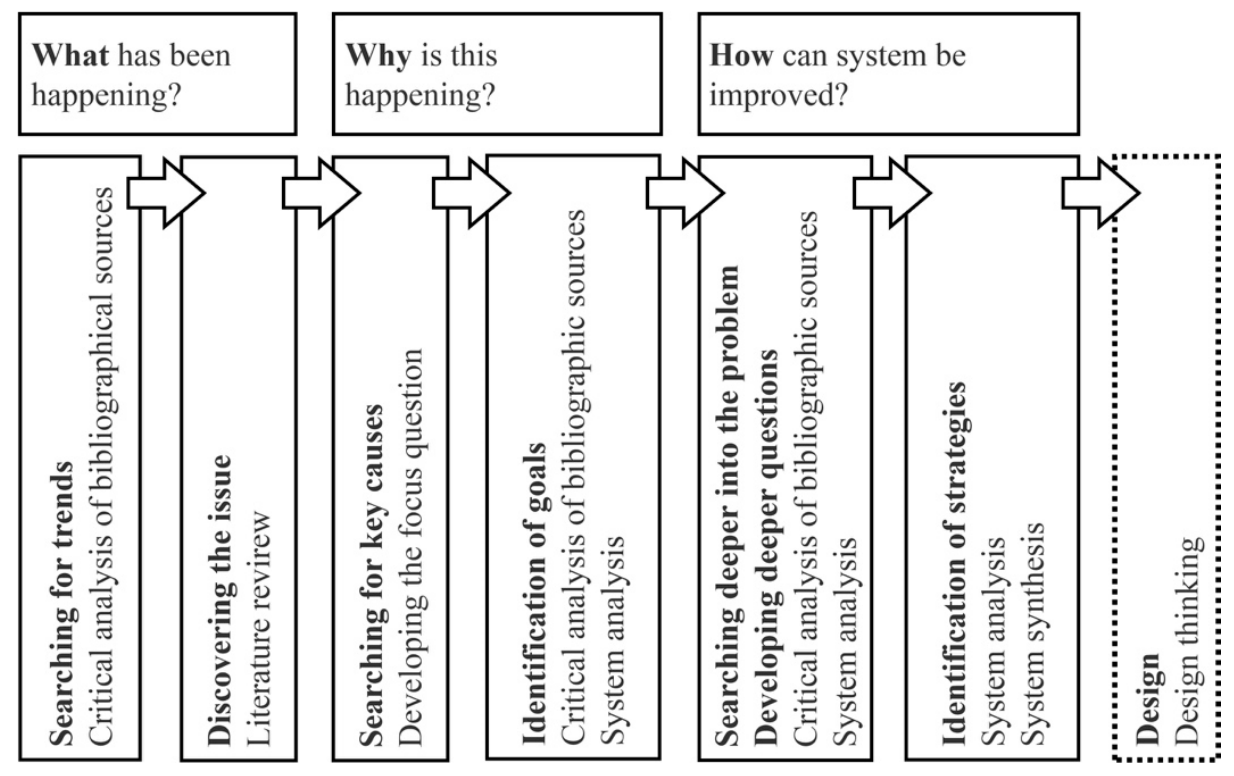

Figure 1. Visual model of system thinking applied in this research.

\section{Results}

\subsection{Criterion of Social Benefits for Buildings Users}

The concept of sustainable development involves a social dimension. Yet, for two decades, environmental and economic issues have taken precedence. The approach which neglected social sustainability failed to generate meaningful change [42]. Today, the humane dimension of sustainability is recognized as fundamental [16]. However, the main problem with social sustainability is that there is little consensus as to what it is or how it could be applied [43], especially because of its qualitative nature [44]. When it comes to the social sustainability of the built environment, the key objective concerns "achieving specific outcomes for the users in terms of functionality, comfort, convenience, accessibility, health, wellbeing" [29] (p. 14). The aim is to create "places that promote wellbeing, by understanding what people need from the places" [17] (p. 16). Wellbeing implies ecological quality based on a balanced relationship between people and their environment, i.e., ecological balance. Within this research, the ecological quality of the building, that is taken as the system boundary, is defined as "the extent to which building performances meet the needs and expectations of its users, related to social and economic benefits achieved with simultaneous protection and improvement of the environment throughout the life-cycle of the building" [30] (p. 22). The goal is to create buildings as functional systems. i.e., to create architectural spaces that contribute to users' life quality and satisfaction by preserving their health and encouraging a sense of security, comfort, and harmony with the environment. This goal is becoming increasingly important, bearing in mind that buildings' economic 
value is also based on user's needs and the ability of building to enable their satisfaction. Economic value is actually the judgment that people make about the importance of the building for maintaining their life and wellbeing [45]. Clients are interested in buildings that can meet their needs to a greater extent, i.e., improve the quality of their activities while reducing the operating and maintenance costs [46]. The above indicates the basic role of buildings, which today, in management theory, are primarily seen as "enablers" that can facilitate processes but also contribute to the opposite [47]. Research shows that architectural spaces, thanks to their qualities, can enhance employee productivity, improve the learning process, or contribute to the faster healing of patients [48-50].

Bearing in mind the above, building social quality assessment must not be reduced to the evaluation of quantitative performances [51]. The need for qualification, not just quantification of the social performances of buildings as functional systems, is also recognized in building sustainability assessment systems that deal with added value [52] The BREEAM (Building Research Establishment Environmental Assessment Method) sustainability assessment method (Watford, UK) includes an indicator which focuses on the impact of a building on the wellbeing of its occupants. The DGNB (German Sustainable Building Council) method (Stuttgart, Germany) considers qualitative sociocultural and functional criteria related to a building's utility value. In this context, based on the analysis of the European standard for assessment of the social performance of buildings [53], the main academic studies dealing with building performance evaluation [52], and European sustainability assessment systems that address social sustainability in a more encompassing way, BREEEAM and DGNB indicators related to social benefits for users throughout the use phase of the building are proposed [30]. Furthermore, this literature review includes representative references that confirm the relevance of these indicators in the context of their relationship with the social aspects of sustainability, that is, their importance for users' health and wellbeing. As such, these indicators are the basis for architectural design quality assessment by assessing the level of quantitative and qualitative performances, but they are also the basis for defining integrated design objectives [30]. In this paper, bearing in mind its thematic framework, the indicators that are primarily analysed concern the load-bearing structure as a subsystem of the building. Based on the above, the review and the critical analysis of the representative literature are conducted focusing on the following aspects: protection and safety, comfort, effective spatial organization, spatial adaptability, and maintenance efficiency.

\subsection{Critical Analysis of Structural Design Based on the Criterion of Social Benefits for Buildings Users}

\subsubsection{Safety and Security during Extreme Events}

The building should have the capacity to resist projected current and future loadings. Additionally, it should have the ability to maintain its function in the case of natural or man-made extreme events [54]. The aim is to provide objective safety and security for users by reducing the degree of damage in case of foreseen and unforeseen events.

In general, a building structure must be designed to resist the loads to which it may be exposed to during the life cycle of the building. Minimum requirements for loads resulting from winds, snow, earthquakes, and explosions specified in codes must be met. However, a reserve in the estimated loads should exist in the case of environmental loads, given that, due to climate change, some loads, such as wind, snow, and temperature, have become unpredictable [55]. Given that a methodology that simultaneously considers prescribed and abnormal loads is still not developed enough, it is necessary to ensure the robustness of the structure, which reduces the possibility of disproportionate collapse due to initial damage in case of unforeseen events $[54,56,57]$. The robustness of the structure is primarily based on ductility, continuity, and redundancy [58]. It should be kept in mind that most structural failures result from defects of connections between structural elements. These connections should be strong as the parts that are connected, thus ensuring robustness against unforeseen actions [59]. 
The specific safety aspect relates to the earthquake resistance of buildings. Analyses show that most existing buildings in Europe are highly vulnerable to earthquakes [60]. The seismic risk keeps increasing given that basic principles of earthquake-resistant design are often not followed in the case of new buildings [61]. Next to the size of the building, the shape of the building is a fundamental parameter that controls its behaviour in the event of an earthquake [62]. Symmetrical and compact forms are favourable to reduce the torsion of a building, i.e., to avoid unpredictable stress concentrations, which can cause local collapse and modification of dynamic behaviour. Additionally, it is necessary to provide more direct load paths within the structure, as well as more even stress distribution. The previous implies the avoidance of structural irregularities in the vertical and horizontal direction, i.e., variations in the structural system, strength, stiffness, and mass. The above is particularly significant because it has been shown that structural irregularities affect a building's performance during an earthquake. They can lead to a reduction in collapse safety and to greater damage [63]. Additionally, one specific problem is that analysis methods often cannot accurately predict the mechanical behaviour of an irregular structure, leading to inadequate design [64]. In addition to the above, the essential characteristics of seismically resistant structures are ductility, deformability, and damageability, which allow the structure to deform without collapse, sustaining damage [65].

The building structure should be made of elements that meet the prescribed fire resistance, i.e., preserve load-bearing capacity, stability, integrity (without cracks, to prevent gas penetration), and thermal insulation properties (in the case of surface structural elements) during a certain required time. These criteria may be required individually or in combination [66]. An approach based on the testing and analysis of the fire resistance of individual structural elements gives results good enough for standard and simple structures. However, this approach can give an inaccurate picture of the fire resistance of the whole structure, especially in the case of non-standard and complex assemblies [67]. Given that the static system largely conditions mechanical resistance of the structure in the event of a fire, one of the key passive fire safety measures is to ensure the redundancy of the structure [68].

Undesirable displacements of building structure can be a consequence of the shrinking and swelling of materials due to changes in relative humidity and temperature in the environment, and also as a consequence of material creep. In the case of mid-rise woodframe construction, given that it is difficult to predict this displacement accurately, it is suggested that a good margin of safety should be added in the design to avoid potential adverse consequences [69], i.e., to prevent unwanted geometric effects.

\subsubsection{Thermal Comfort}

Thermal comfort refers to satisfaction with the thermal environment. The importance of thermal comfort is indicated by studies that show that the thermal environment has a significant impact on the health and productivity of building users [70]. Given that each person experiences thermal conditions differently, the aim is to provide average, optimal thermal comfort conditions in accordance with the function of architectural space. Thermal comfort indicators related to building structure are air temperature, mean radiant temperature, and relative air humidity.

Adequate building structure solution can contribute to thermal comfort while reducing energy consumption for heating and cooling. In this sense, building structure solutions should be conditioned by climatic factors. The aim is to minimize temperature fluctuations in interior spaces. Therefore, it is necessary to provide adequate thermal resistance of the structure while minimizing thermal bridges [71]. Additionally, it is necessary to achieve sufficient airtightness of assembly, i.e., reduction of air leaking [72]. When it comes to air leakage, non-monolithic structural assemblies are more sensitive, especially those made of materials that are sensitive to the effects of wetting and drying in terms of dimensional stability. Thermal comfort can be enhanced by the appropriately applied thermal mass of exposed structural elements [73]. In temperate climate areas, during the summer day, exposed structural elements cooled during the night (naturally or forcedly) can have a lower 
temperature to the interior air temperature and can contribute to the cooling effect [74]. On the other hand, during the winter day, the heated structure can have a higher temperature than the interior air temperature and thus contribute to the effect of heating, i.e., feeling of comfort. The thermal properties of materials from which building structure is made affect the mean radiant temperature, which is an important element of thermal comfort [75]. The sense of comfort in the interior spaces is also affected by the ratio of air temperature and air humidity. The applied structural materials will influence interior air humidity, i.e., their hygroscopic properties [76]. Steel structures do not participate in the regulation of interior air humidity. On the other hand, wood and concrete can absorb moisture from the air and dissipate it, thus contributing to air humidity regulation proportionally to the degree of absorption [77]. It should be kept in mind that equally significant wetting and drying process of the structure can be disrupted in the case of highly insulated buildings, thereby increasing the risk of the occurrence of condensation and the damage caused by wetting [78].

\subsubsection{Air Comfort}

Air comfort refers to conditions that provide the required amount of clean air, i.e., indoor air quality, which is without risk to the health of the building users. The air quality affects the health of users and their ability to perform activities [79]. The aim is to provide the required amount of fresh air to minimize chemical air pollutants and radiation and the presence of microbes, particles, and microfibers. Additionally, the aim is to minimize the presence of unpleasant odours.

The indoor air quality will be affected by the possibility of changing the air through the building envelope. If structural materials in the façade zone are air permeable, higher air quality will be achieved [80]. Additionally, in this way, the possibility of excessive wetting of walls and mould occurrence will be reduced. The risk of mould occurrence, which is a serious concern for indoor air quality, is higher in thermal bridge zones [81]. Additionally, sensitive places are structural element joints that slacken due to the effects of various loads, which allows the penetration of moisture and the development of mould [82]. Particularly sensitive are modern assemblies with an increased amount of insulation that dry more slowly, in whom the risk of condensation and mould growth is increased [83]. The building structure has been indicated as one of the major reasons for the elevated volatile organic compound (VOC) concentration in buildings [84], with possible negative health effects. These emissions can predominantly be related to thermal insulation materials within the building structure, stay in place formwork for concrete structures, wood-based structural elements, pigments and coatings for concrete, and wood and steel preservatives. Therefore, when it comes to indoor air quality, the application of low-emission materials and products is advised [85]. In the context of the above, besides the required performance characteristics, construction material selection should consider the possible presence of dangerous substances $[53,86]$ relevant to indoor air quality.

\subsubsection{Acoustic Comfort}

The acoustic environment in the interior space results from the sound coming from different sources. Sound sources can be related to the exterior environment, installed building systems, and user's speech and activities. The aim is to reduce or eliminate unwanted sounds, i.e., noise, and achieve the appropriate level and quality of wanted sounds, minimize negative effects on user's health, and increase the feeling of comfort $[87,88]$.

It is necessary to control the noise on the transmission paths by using acoustically efficient materials and assemblies that enable better sound control, i.e., adequate insulation from the airborne and impact sound. The main acoustic condition for partitions refers to the minimum values of their insulation properties that must be achieved in individual positions in the building, according to users' activities that dictate the conditions that should be satisfied $[53,89,90]$. The value of sound reduction indices and impact sound insulation level depend on the physical properties of partitions: the surface mass and 
complexity of its internal structure [91]. Instead of increasing the surface mass, sound insulation improvement can be effectively achieved by forming discontinuities in the partition internal structure. This can be achieved by forming sandwich structures consisting of two or more layers of solid material between which there is a layer of air or porous absorption material [92]. When it comes to insulation from impact sound, contemporary floor structures usually imply additional layers of floor or ceiling to ensure adequate acoustic performances $[93,94]$. However, when it comes to prefabricated systems, especially those made of elements of small surface mass, the degree of sound insulation between two rooms cannot be determined only based on the insulating properties of individual partitions. In such systems, flanking transmission, or indirect transmission of airborne and impact sound, which refers to the transmission of sound vibrations mainly through the connections of structural elements, can be dominant [95]. When it comes to the quality of wanted sounds, i.e., sound quality in accordance with a space's function, it is necessary to apply materials with adequate acoustic performances, within assemblies with adequate shape and arrangement of spatial elements, given that emitted sound is altered by architectural space due to sound reflection, absorption, and diffusion phenomena occurring over its surfaces [96].

\subsubsection{Visual Comfort}

Light is essential for perceiving space, shapes, colours, and textures, and understanding the arrangement of spatial elements. The role of light in architectural spaces is related to three domains: health, safety, and the experience of space $[97,98]$. Visual comfort involves the following: the required amount of natural light, with simultaneous control of direct sunlight; sufficient surface illumination level, according to specific visual tasks and spatial uniformity of illumination; glare control; and lighting performances in accordance with the space's function.

The type of load-bearing structure affects the possibility of forming openings, that is, conceptualizing their position, size, and shape, which are related to daylighting [99] and overall lighting quality. Additionally, applied materials within the exposed building structure, which are characterized by a specific structure, colour, and texture, and thus by a certain degree of reflection, as well as shape and arrangement of exposed structural elements, contribute to the quality of lighting, affecting the light distribution, intensity, and colour $[100,101]$.

\subsubsection{Electromagnetic Radiation Protection}

Long-term exposure to electromagnetic fields, especially fields with a frequency of 50$60 \mathrm{~Hz}$, has harmful effects on the user's health [102]. Therefore, it is necessary to limit the exposure, i.e., the electric and magnetic field strength [103], especially in spaces where longterm and chronic exposure of users is expected. The aim is to minimize electromagnetic pollution by identifying sources and applying measures to limit their impacts.

Metal elements in building structure can shield a building against electromagnetic fields, but they can also increase the strength of electromagnetic fields in indoor spaces due to reflections and superposition of electromagnetic waves [77]. Furthermore, research indicates that highly reinforced concrete walls and floors can amplify the effects of electromagnetic radiation [104]. In the context of the above, it is necessary to understand the electromagnetic properties of building materials, i.e., transmission and reflection, in order to apply measures to effectively reduce electromagnetic field strength in indoor spaces [105].

\subsubsection{Effective Spatial Organization}

An important qualitative aspect related to the social benefits for building users, which concerns the added value, refers to the realization of the effective spatial organization of user's activities. Therefore, it is necessary to ensure spatial functionality [106,107], that is, undisturbed realization of planned activities, which implies meeting space standards 
and creating adequate relations and communication between individual spatial zones. In arranging these relations, it should be kept in mind that spatial organization is actually the organization of people's relations [108].

Structural form largely conditions the spatial organization of user's activities, that is, the functionality of architectural space. If the physical spaces, defined by structural form, do not coincide with the social ones, defined by the user's activities, the building will not be perceived as correct [109]. In that context, the aim is to achieve effective structural form for a given social space of the building. It is an approach to structural design based on careful harmonization of structural form with people and their needs [110].

\subsubsection{Functional Adaptability}

The user's needs that a building or its parts should meet change over time [111]. In that sense, an important precondition for extending the useful life of a building and maintaining its value is its capacity to accommodate change [112].

The applied building materials and constructive system solutions have a strong impact on a building's adaptability and, consequently, its resilience [113]. The realization of new activities is largely conditioned by building structure solutions. In order to enable changes in space function with a low level of resource consumption, it is necessary to form larger spans (from minimum 7.5 to $12 \mathrm{~m}$ ) and higher floor-to-ceiling heights (minimum $2.7 \mathrm{~m}$ ) [114-116]. A structural floor system should accommodate several mechanical and electrical service distribution schemes based on different space functions [117]. The structural concept should enable the easy subsequent formation of openings in interior bearing partitions and the façade zone. Additionally, the possibility of the simple realization of connections of new structural elements with the existing ones should be provided. There should be a reserve in the load-bearing capacity of building structures [118], primarily in the value of the live load, according to expected new functions, but also in relation to estimated building upgrades [112,118]. It is necessary to enable easy separation of elements that have a significantly different technical and economic lifespan. In that context, the connections of elements made with screws are more favourable than glued, welded, or casting in situ [119]. The physical separability of key building layers are as follows: building structure (average lifespan of over 50 years), installation systems (average lifespan approximately 15 years), and light internal partitions (average lifespan approximately 6 years), and these should be achieved with simultaneous integration on the functional level [120].

\subsubsection{Building Maintenance Efficiency}

Building maintenance refers to a series of activities aimed at ensuring the efficient functioning of a building and maintaining its value [121]. The aim is to provide maintenance efficiency during expected service life, which implies maximum effects with a minimum investment of human, material, and financial resources [122].

Building maintenance efficiency is related to the maintainability of its structure [53], which is conditioned by achieved reliability, durability, and accessibility for its maintenance, defined in the design phase [123]. The building structure should have a satisfactory level of reliability during the service life [124], during which it should suffer no or minimal damage, especially because structural repairs can be technically demanding and economically unsustainable [125]. The building structure should be designed for optimal durability, with regular maintenance, which corresponds to the average estimated service life for the intended function [126]. The building structure service life will depend on the degree of exposure to various environmental influences, quality of applied materials, applied protection measures, global conception and details, quality of construction work, and maintenance quality [123]. It is necessary to understand the physical and chemical properties of applied structural materials and the mechanisms of their deterioration (mechanical, climatic, chemical, biological) in the context of local environmental conditions [124]. In addition to adequate material selection and quality [122,127] and adequate protection measures, adequate details will provide greater protection of components from degradation 
factors [128]. The details should be designed to eliminate water accumulation on structural elements, which may occur because of rainwater penetration, condensation due to air leakage, condensation due to diffusion of water vapour, and installation leaks. It is necessary to minimize these effects primarily through the possibility of drying. In the context of the above, the use of partially hygroscopic materials which are not sensitive to moisture is favourable, in assemblies that allow drying [78]. It is necessary to provide easy access to all parts of the building structure, so that maintenance can be carried out [122]. It is necessary to provide easy repairs and easy replacement of damaged elements.

\subsection{Conceptual Framework for Structural Design Based on the Criterion of Social Benefits for Building Users}

After review and critical analysis of the representative literature, conducted with the aim of responding to the research question: "According to which principles should building structures be designed in order to achieve social benefits for building users?", a conceptual framework for structural design is derived. Based on the criteria of social benefits for building users, key quantitative and qualitative structural design criteria are synthesized and presented in a structured and systematic way. In order to manage complexity, bounded concerns were considered, ensuring that one selected issue is the concern of the systembuilding as a whole. Table 1 shows key socially-based structural design criteria in relation to the criteria of social benefits for building users: safety and security during extreme events, thermal, air, acoustic, and visual comfort, electromagnetic radiation protection, effective spatial organization, functional adaptability, and building maintenance efficiency.

Keeping in mind changes in the design paradigm, broadening the theoretical basis, and increasing in complexity, the given conceptual framework should enable more comprehensive and more efficient decision-making during systemic design and optimization of buildings within the interdisciplinary team that is working on the development of user-centric sustainable building concepts.

Table 1. Conceptual framework for structural design based on the criterion of social benefits for building users.

\begin{tabular}{|c|c|}
\hline $\begin{array}{l}\text { Criteria of Social Benefits for } \\
\text { Building Users-Indicators } \\
{[1,2,16-30,42-53]}\end{array}$ & $\begin{array}{c}\text { Socially-Based Criteria for Design and Assessment of } \\
\text { Building Structures }\end{array}$ \\
\hline $\begin{array}{l}\text { Safety and Security During } \\
\text { Extreme Events [54] }\end{array}$ & [55-69] \\
\hline $\begin{array}{l}\text { - } \quad \text { capacity of a building to resist projected loadings } \\
\text { ability of a building to maintain its function in the case of } \\
\text { extreme events }\end{array}$ & $\begin{array}{l}\text { - } \quad \text { reserves in estimated loads } \\
\text { - } \quad \text { redundancy } \\
\text { reduction of building torsion-symmetrical and compact } \\
\text { forms } \\
\text { - } \quad \text { more even stress distribution } \\
\text { - } \quad \text { avoidance of structural irregularities in the vertical and } \\
\text { horizontal direction, i.e., variations in the structural } \\
\text { system, strength, and stiffness } \\
\text { - } \text { mass reduction and uniform mass distribution } \\
\text { deformability and damageability of building } \\
\text { structure-failure announcement } \\
\text { adequate design of connections between structural } \\
\text { elements } \\
\text { application of structural elements that meet the prescribed } \\
\text { fire resistance and thermal insulation properties } \\
\text { adequate measures to reduce the effects of shrinkage, } \\
\text { swelling, and creep of structural materials }\end{array}$ \\
\hline
\end{tabular}


Table 1. Cont.

\begin{tabular}{lc}
\hline Criteria of Social Benefits for & Socially-Based Criteria for Design and Assessment of \\
Building Users-Indicators & Building Structures \\
{$[1,2,16-30,42-53]$} &
\end{tabular}

\begin{tabular}{ll} 
& Thermal Com \\
\hline & \\
- $\quad$ air temperature \\
- $\quad$ relan radiane air humidity
\end{tabular}

- $\quad$ quantity of fresh air

- $\quad$ amount of chemical air pollutants

- radiation level

- presence of microbes

- $\quad$ amount of particles and micro fibres

- $\quad$ presence of unpleasant odour materials

\section{Acoustic Comfort $[87,88]$}

- background/ambient noise level from external sources, installed

- $\quad$ systems, human speech and activity (sound pressure level in space)

- $\quad$ acoustic performances in accordance with space's function

[71-78]

- $\quad$ adequate thermal resistance of building structure

- minimization of thermal bridges-low framing factor

- $\quad$ sufficient airtightness of assembly-adequate connection details and dimensional stability of structural materials

- $\quad$ adequate thermal mass of building structure

- $\quad$ adequate colours of exposed structural elements

- adequate radiant temperature of surface structural elements

- $\quad$ adequate hygroscopic properties of structural materials-the possibility of regulating the humidity of interior spaces, i.e., wetting and drying of the building structure
[80-86]

- air permeable surface structural elements in the façade zone

- elimination of occurrence of excessive moisture in façade zone and thus occurrence of mould

$\checkmark$ air permeable surface structural elements

details that minimize thermal bridging

adequate connections of structural elements

- $\quad$ minimization of the presence of structural materials that release chemical air pollutants, radiation, particles, microfibers, and unpleasant odour [89-96]

- $\quad$ adequate sound reduction index of structural elements

- $\quad$ adequate impact sound insulation level of structural elements

- $\quad$ low structural flanking transmission, i.e., low indirect transmission of airborne and impact sound

$\bigcirc$ adequate materialization of structural elements $\bigcirc$ adequate connection details

- $\quad$ adequate acoustic performances of structural materials and assemblies

$\bigcirc$ adequate materialization of structural elements

adequate shapes and disposition of structural elements

\begin{tabular}{|c|c|}
\hline Visual Comfort $[97,98]$ & [99-101] \\
\hline $\begin{array}{ll}\text { - } & \text { percentage of area under daylight } \\
\text { - } & \text { control of direct sunlight } \\
\text { - } & \text { illumination level } \\
\text { - } & \text { uniformity of illumination } \\
\text { - } & \text { glare control, direct or reflective } \\
\text { - } & \text { lighting performances in accordance with space's function }\end{array}$ & $\begin{array}{l}\text { - possibility of forming openings-adequate sizes, shapes, } \\
\text { and positions of openings within the building structure } \\
\text { - adequate shape of structural elements } \\
\text { - adequate structure, colour, and texture of materials of } \\
\text { exposed } \\
\text { building structure }\end{array}$ \\
\hline $\begin{array}{l}\text { Electromagnetic Radiation } \\
\text { Protection [102] }\end{array}$ & [103-105] \\
\hline - $\quad$ electromagnetic field strength & - $\quad$ adequate electromagnetic properties of structural materials \\
\hline
\end{tabular}


Table 1. Cont.

\begin{tabular}{|c|c|}
\hline $\begin{array}{l}\text { Criteria of Social Benefits for } \\
\text { Building Users-Indicators } \\
{[1,2,16-30,42-53]}\end{array}$ & $\begin{array}{c}\text { Socially-Based Criteria for Design and Assessment of } \\
\text { Building Structures }\end{array}$ \\
\hline $\begin{array}{c}\text { Effective Spatial } \\
\text { Organization }[106,107]\end{array}$ & [108-110] \\
\hline \multirow{2}{*}{$\begin{array}{l}\text { - } \begin{array}{l}\text { degree of realization of space standards } \\
\text { relations and communications between individual spatial } \\
\text { zones }\end{array} \\
\text { Functional Adaptability }[111,112]\end{array}$} & $\begin{array}{l}\text { - effective structural form for a given social spaces of the } \\
\text { building }\end{array}$ \\
\hline & [113-120] \\
\hline $\begin{array}{ll}\text { - } & \text { possibility of realization of various activities } \\
\text { - } & \text { possibility of different spatial arrangement and furnishing } \\
\text { - } & \text { adaptability of building systems } \\
\text { - } & \text { possibility of intervention in relation to solution of the } \\
\text { building's envelope }\end{array}$ & $\begin{array}{l}\text { disposition of structural elements which enables change of } \\
\text { space's function } \\
\text { structural concept that enables the easy subsequent } \\
\text { formation of openings } \\
\text { reserve in the load-bearing capacity of the building } \\
\text { structure } \\
\text { easy separation of key layers of the building-building } \\
\text { structure, installations, and light internal partitions }\end{array}$ \\
\hline $\begin{array}{l}\text { Building Maintenance } \\
\text { Efficiency }[121,122]\end{array}$ & [123-128] \\
\hline $\begin{array}{ll}\text { - } & \text { accessibility for maintenance } \\
\text { - } & \text { maintenance frequency } \\
\text { - } & \text { scope of maintenance work } \\
\text { maintenance method-type of work and work } \\
\text { organization }\end{array}$ & $\begin{array}{l}\text { - } \quad \text { reliability and optimal durability of the building structure } \\
\text { known mechanisms of structural materials } \\
\text { deterioration } \\
\text { adequate material quality and protection measures } \\
\text { adequate global structural concept and details } \\
\text { - } \quad \text { adequate method of construction and maintenance } \\
\text { - } \quad \text { low maintenance frequency } \\
\text { - } \quad \text { possibility of easy repair }\end{array}$ \\
\hline
\end{tabular}

\section{Discussion and Conclusions}

Sustainable building involves reducing negative environmental impact with a simultaneous increase in life quality [1]. In order to achieve these goals, a user-centric approach in building design should be applied [29]. It is a qualitatively new holistic approach to building design [6], i.e., an integrated design approach which gradually replaces the reductionistic one based on a limited number of criteria and a linear principle. The aim of an integrated design approach is to optimize building performances in accordance with integrated design objectives [30,51-53]. Within this approach, the structural design aims to improve the overall performances of a building as a whole. In this process, the building structure is created on the basis of a series of new interrelated parameters concerning the building's social sustainability.

A review of the literature showed that, despite the recognized importance of social sustainability, there is only a small amount of research related to structural design in this context, especially those that apply a systemic approach and deal with the topic comprehensively. Given the above, this research dealt with identifying strategies for structural design based on the criterion of social benefits for building users. The subject analysis of representative literature was performed in accordance with the research question: "According to which principles should building structures be designed in order to achieve social benefits for building users?" The identified strategies were the basis for deriving the conceptual framework for structural design to support the decision-making process related to systemic, integrated design and optimization of building structures. The following aspects of the social quality of buildings were analysed: safety and security, thermal comfort, air comfort, acoustic comfort, visual comfort, electromagnetic radiation protection, 
spatial organization, functional adaptability, and building maintenance. Within each aspect, a set of performance indicators were given. For every aspect and performance indicator, a critical analysis of representative literature was conducted. Based on the perceived problems, applied solutions, and examples of good practice, a set of criteria for the integrated design and evaluation of building structures, harmonized with quantitative and qualitative indicators of social benefits for building users, is synthetized and presented in a structured and systematic way.

The presented integrated literature review indicates the need for the application of a systemic approach, based on comprehending the possible forms of connections and dependencies of subsystems of the building, building structure, and structural materials, as well as from comprehending the behaviour of these subsystems directed towards achieving the goal of a system-building. It is a user-oriented performance-based approach to structural design that, in its practical operationalization, should provide design and assessment of buildings of various quantitative and qualitative properties, with a higher common property-social quality. This approach to structural design is based on the principle of contextuality, where each solution derives from its inherent set of parameters. Multiple influencing factors condition the building structure solution. In addition to integrated design objectives, which can be considered global, the outcomes will be affected by the conditions of the local environment and users' needs in a given time context [129]. It is a systemic approach to building design that requires systemic thinking and the continuous interaction of all participants in the design process, which implies interdisciplinarity and transdisciplinarity in order to explore complex interdependencies of multiple aspects from which, in a nonlinear, iterative process, ideas and concepts that enhance wellbeing emerge [130].

Bearing in mind the complex nature of a given form of structural design, based on multiple analyses of many aspects of social sustainability, further research related to the development of strategies for implementing this design concept in engineering practice is needed. In addition to improving the educational process and educational content $[37,131]$, which should include systems thinking within an integrated systemic approach to building design, implementing the concept of user-oriented design in engineering practice implies further development of a legal framework and standards related to social sustainability. This is also emphasized by the European Commission, which insists on the development of a certification framework for healthiness and wellbeing of the built environment, "so that user-centric approaches become a reality" [29] (p. 14).

Author Contributions: Conceptualization, A.N.; methodology, A.N. and J.M.; validation, A.N. and J.M.; formal analysis, A.N.; investigation, A.N. and J.M.; data curation, A.N. and J.M.; writing-original draft preparation, A.N.; writing - review and editing, A.N. and J.M.; visualization, A.N. and J.M. All authors have read and agreed to the published version of the manuscript.

Funding: This research was funded by the Ministry of Education, Science and Technological Development of the Republic Serbia, grant number 451-03-68/2020-14/200090. The research was carried out at the research labs of the University of Belgrade-Faculty of Architecture, Laboratory for Innovative Structures in Architecture-LISA.

Institutional Review Board Statement: Not applicable.

Informed Consent Statement: Not applicable.

Conflicts of Interest: The authors declare no conflict of interest. The funders had no role in the design of the study; in the collection, analyses, or interpretation of data; in the writing of the manuscript; or in the decision to publish the results. 


\section{References}

1. Working Group for Sustainable Construction. Competitiveness of the Construction Industry: An Agenda for Sustainable Construction in Europe; Working Group for Sustainable Construction: Brussels, Belgium, 2001. Available online: https:/ / onlinebookshop.villareal. fi/docs/AnAgendaforSustainableConstructioninEurope.pdf (accessed on 18 September 2020).

2. Republička agencija za prostorno planiranje. Strategija Prostornog Razvoja Republike Srbije 2009-2013-2020; Republička Agencija za Prostorno Planiranje, Ministarstvo žIvotne Sredine i Prostornog Planiranja: Belgrade, Serbia, 2009.

3. Blagojević, L.J.; Ćirović, D. Klimatske promene i estetika savremene arhitekture. In Uticaj Klimatskih Promena na Planiranje $i$ Projektovanje; Đokić, V., Lazović, Z., Eds.; Univerzitet u Beogradu, Arhitektonski fakultet: Belgrade, Serbia, 2011 ; pp. 19-33.

4. Design Council. Design Council Annual Review 2002; Design Council: London, UK, 2002.

5. Van der Ryn, S.; Cowan, S. Ecological Design; Island Press: Washington, DC, USA, 2007.

6. Birkeland, J. Design for Sustainability: A Sourcebook of Integrated Eco-Logical Solutions; Earthscan: London, UK, 2002.

7. Kestner, D.M.; Goupil, J.; Lorenz, E. (Eds.) Sustainability Guidelines for the Structural Engineer; ASCE: Reston, VA, USA, 2010.

8. Danatzko, J.M.; Sezen, H. Sustainable structural design methodologies. Pract. Period. Struct. Des. Constr. 2011, 16, 186-190. [CrossRef]

9. Ahmed, N.; Hussain, A.; Ahmed, S. Sustainable Structural Design. IJREAS 2012, 2, 19-30.

10. Miller, D.; Doh, J.-H. Incorporating sustainable development principles into building design: A review from a structural perspective including case study. Struct. Des. Tall Spec. Build. 2014, 24, 421-439. [CrossRef]

11. Tsimplokoukou, K.; Tornaghi, M.L.; Negro, P. A sustainable structural design method to analyze structural and environmental performances of a building. In Proceedings of the Structural Engineering: Providing Solutions to Global Challenges, Proceedings of IABSE Conference, Geneva, Switzerland, 23-25 September 2015.

12. Pongiglione, M.; Calderini, C. Sustainable structural design: Comprehensive literature review. J. Struct. Eng. 2016, $142,04016139$. [CrossRef]

13. Caruso, M.C.; Lamperti, T.M.; Negro, P. Applicability of the sustainable structural design (SSD) method at urban/regional/national level. In Proceeding of the 16th European Conference on Earthquake Engineering, Thessaloniki, Greece, 18-21 June 2018.

14. Nenadović, A.; Tekić, Ž.; Đorđević, S. Environmentally-based structural design criteria for buildings. Therm. Sci. 2018, 22, 1047-1058. [CrossRef]

15. Vilutiene, T.; Kumetaitis, G.; Kiaulakis, A.; Kalibatas, D. Assessing the sustainability of alternative structural solutions of a building: A case study. Buildings 2020, 10, 36. [CrossRef]

16. Shirazi, M.R.; Keivani, R. Critical reflections on the theory and practice of social sustainability in the built environment-A meta-analysis. Local Environ. 2017, 22, 1526-1545. [CrossRef]

17. Woodcraft, S.; Bacon, N.; Caistor-Arendar, L.; Hackett, T. Design for Social Sustainability: A Framework for Creating Thriving New Communities; Social Life: London, UK, 2012.

18. Mehan, A.; Soflaei, F. Social sustainability in urban context: Concepts, definitions, and principles. In Architectural Research Addressing Societal Challenges, Proceedings of the EAAE ARCC 10th International Conference, Lisbon, Portugal, 15-18 June 2016; Costa, M.C., Roseta, F., Lages, J.P., Costa, S.C., Eds.; Taylor \& Francis Group: Abingdon, UK, 2017; pp. $293-299$.

19. Krefis, A.C.; Augustin, M.; Schlünzen, K.H.; Oßenbrügge, J.; Augustin, J. How does the urban environment affect health and well-being? A systematic review. Urban Sci. 2018, 2, 21. [CrossRef]

20. Chasey, A.D.; Agrawal, N. A case study on the social aspect of sustainability in construction. In Proceedings of the 2012 International Conference on Sustainable Design and Construction, Fort Worth, TX, USA, 7-9 November 2012.

21. Zuo, J. Social sustainability in construction-An explorative study. Int. J. Constr. Manag. 2014, 12, 51-63. [CrossRef]

22. Pocock, J.; Steckler, C.; Hanzalova, B. Improving socially sustainable design and construction in developing countries. Procedia Eng. 2016, 145, 288-295. [CrossRef]

23. Wang, H.; Zhang, X.; Lu, W. Improving social sustainability in construction: Conceptual framework based on social network analysis. J. Manag. Eng. 2018, 34, 05018012. [CrossRef]

24. Kamaruddin, T.; Razali, A.H.; Abd, G.S. Social aspect implementation in sustainable construction. In Proceedings of the 4th International Conference on Construction and Building Engineering \& 12th Regional Conference in Civil Engineering, Langkawi, Malaysia, 20-22 August 2019.

25. Smith, D.; Beeck, S.; Lommerse, M.; Metcalfe, P. An Introduction to Social Sustainability and Interior Architecture. In Perspectives on Social Sustainability and Interior Architecture; Smith, D., Lommerse, M., Metcalfe, P., Eds.; Springer: Singapore, 2014 ; pp. 1-11.

26. Kefayati, Z.; Moztarzadeh, H. Developing effective social sustainability indicators in architecture. Bull. Environ. Pharmacol. Life Sci. 2015, 4, 40-56.

27. Klimovich, K.; Nicolle, R.; Anagnostopoulos, F.; de Groote, M.; Staniaszek, D. Building 4 People: People-Centric Buildings for European Citizens. Buildings 2030. 2017. Available online: https://bpie.eu/wp-content/uploads/2017/12/White-Paper2017.pdf (accessed on 11 December 2020).

28. Lami, I.M.; Mecca, B. Assessing Social Sustainability for Achieving Sustainable Architecture. Sustainability. 2021, $13,142$. [CrossRef]

29. European Commission. Built4People: People-Centric Sustainable Built Environment; Publication Office of the European Union: Brussel, Belgium, 2020. 
30. Nenadović, A. Integrisano projektovanje konstruktivnih sistema zasnovanih na primeni ferocementa. Ph.D. Thesis, Univerzitet u Beogradu, Belgrade, Serbia, 2014.

31. Torraco, R.J. Writing Integrative Literature Reviews: Guidelines and Examples. Hum. Resour. Dev. Rev. 2005, 4, 356-367. [CrossRef]

32. Snyder, H. Literature review as a research methodology: An overview and guidelines. J. Bus. Res. 2019, 104, 333-339. [CrossRef]

33. Whittemore, R.; Knafl, K. The integrative review: Updated methodology. J. Adv. Nurs. 2005, 52, 546-555. [CrossRef]

34. Bertalanffy, L. General System Theory: Foundations, Development, Application; George Braziller: New York, NY, USA, 1976.

35. Khalil, N.; Kamaruzzaman, S.N.; Baharum, M.R. Ranking the indicators of building performance and the users' risk via Analytical Hierarchy Process (AHP): Case of Malaysia. Ecol. Indic. 2016, 71, 567-576. [CrossRef]

36. Shaked, H.; Schechter, C. Systems Thinking for School Leaders; Springer: Cham, Switzerland, 2017.

37. Arnold, R.D.; Wade, J.P. A definition of systems thinking: A systems approach. Procedia Comput. Sci. 2015, 44, 669-678. [CrossRef]

38. Senge, P. The Fifth Discipline: The Art and Practice of the Learning Organization; Doubleday: New York, NY, USA, 2006.

39. Andrew, T.N.; Petkov, D. The need for a systems thinking approach to the planning of rural telecommunications infrastructure. Telecomm. Policy. 2003, 27, 75-93. [CrossRef]

40. Gharajedaghi, J. Systems Thinking, Managing Chaos and Complexity: A Platform for Designing Business Architecture; Morgan Kaufmann: Burlington, MA, USA, 2011.

41. Greer, D. The Art of Separation of Concerns. Available online: https://aspiringcraftsman.com/2008/01/03/art-of-separation-ofconcerns (accessed on 5 May 2020).

42. Vallance, S.; Perkins, H.C.; Dixon, J.E. What is social sustainability? A clarification of concepts. Geoforum 2011, 42, 342-348. [CrossRef]

43. McGuinn, J.; Fries-Tersch, E.; Jones, M.; Crepaldi, C.; Masso, M.; Kadarik, I.; Samek Lodovici, M.; Drufuca, S.; Gancheva, M.; Geny, B. Social Sustainability: Concepts and Benchmarks; Policy Department for Economic, Scientific and Quality of Life Policies: Luxembourg, 2020.

44. Wandahl, S.; Lund, L.; Neve, H.; Jensen, S.R. Social Sustainability in Modelling of Value Creation in Housing Refurbishment. In Proceedings of the 10th Nordic Conference on Construction Economics and Organization, Tallinn, Estonia, 7-8 May 2019.

45. Menger, C. Principles of Economics; Ludwig von Mises Institute: Auburn, AL, USA, 2007.

46. Construction Task Force. Rethinking Construction; Department of Trade and Industry: London, UK, 1998.

47. McDougall, G.; Kelly, J.R.; Hinks, K.; Bititci, U.S. A review of the leading performance measurement tools for assessing buildings. J. Facil. Manag. 2002, 1, 42-153. [CrossRef]

48. CABE; BCO. The Impact of Office Design on Business Performance; Commission for Architecture and the Built Environment and the British Council for Offices: London, UK, 2005.

49. Kjærvang, U.; Bækgaard, B.; Krogh-Christensen, K. Æstetik, ja tak,-En Inspirationsbog om Hverdagsæstetik $i$ Grundskolen; Dansk Center for Undervisningsmiljø: Randers, Danmark, 2003.

50. Ulrich, R.; Xiaobo, Q.; Zimring, C.; Anjali, J.; Choudhary, R. The Role of the Physical Environment in the Hospital of the 21st Century: A Once-in a-Lifetime Opportunity; The Center for Health Design: Concord, CA, USA, 2004.

51. Cucuzzella, C. Analyzing Eco-Architecture Beyond Performance; Éditions JFD inc.: Montreal, QC, Canada, 2020.

52. Sotsek, N.C.; Leitner, D.S.; Santos, A.P.L. A systematic review of Building Performance Evaluation criterias (BPE). Rev. ALCONPAT. 2019, 9, 1-14. [CrossRef]

53. EN 16309:2014+A1:2014. Sustainability of Construction Works-Assessment of Social Performance of Buildings—Calculation Methodology; BCI Standards Limited: Reading, UK, 2014.

54. Stochino, F.; Bedon, C.; Sagaseta, J.; Honfi, D. Robustness and Resilience of Structures under Extreme Loads. Adv. Civ. Eng. 2019, 19, 4291703. [CrossRef]

55. Demonceau, J.; Comeliau, L.; Jaspart, J. Robustness of building structures-Recent developments and adopted strategy. Steel Constr. 2011, 4, 166-170. [CrossRef]

56. Adam, J.M.; Parisi, F.; Sagaseta, J.; Lu, X. Research and practice on progressive collapse and robustness of building structure in the 21st century. Eng. Struct. 2018, 173, 122-149. [CrossRef]

57. England, J.; Agarwal, J.; Blockley, D. The vulnerability of structures to unforeseen events. Comput. Struct. 2008, 86, 1042-1051. [CrossRef]

58. Starossek, U.; Haberland, M. Measure of structural robustness-Requirements and applications. In Structures 2008: Crossing Borders, Proceedings of the Structures Congress 2008, Vancouver, BC, Canada, 24-26 April 2008; Anderson, D., Ventura, C., Harvey, D., Hoit, M., Eds.; ASCE: Reston, VA, USA, 2008.

59. Chapman, J.C. Learning from failures. In Learning from Construction Failures: Applied Forensic Engineering; Campbell, P., Ed.; Whittles Publishing: Caithness, UK, 2001; p. 100.

60. Palermo, V.; Tsionis, G.; Sousa, M.L. Building Stock Inventory to Assess Seismic Vulnerability across Europe; Publications Office of the European Union: Luxembourg, 2018.

61. Bachmann, H. Seismic Conceptual Design of Buildings—Basic Principles for Engineers, Architects, Building Owners, and Authorities; BBL Vertrieb Publikationen: Bern, Switzerland, 2003.

62. Llunji, M. Seismic Architecture: The Architecture of Earthquake Resistant Structures; MSPROJECT: Ulcinj, Montenegro, 2016. 
63. Applied Technology Council. Assessing Seismic Performance of Buildings with Configuration Irregularities Calibrating Current Standards and Practices; FEMA P-2012; Applied Technology Council: Redwood City, CA, USA, 2018.

64. ASCE/SEI 7-16. Minimum Design Loads and Associated Criteria for Buildings and Other Structures; American Society of Civil Engineers: Reston, VA, USA, 2017.

65. Applied Technology Council. Seismic Performance Assessment of Building; FEMA-P-58-1; Applied Technology Council: Redwood City, CA, USA, 2012.

66. Vassart, O.; Zhao, B.; Cajot, L.; Robert, F.; Meyer, U.; Frangi, A. Eurocodes: Background and Applications. Structural Fire Design. Worked Examples; Poljansek, M., Kamenarova, B.N., Raposo, M.L., Mayor, M., Dimova, S., Pinto Vieira, A., Eds.; Publications Office of the European Union: Luxembourg, 2014.

67. Purkiss, J.A. Fire Safety Engineering Design of Structures, 2nd ed.; Butterworth-Heinemenn-Elsevier: Oxford, UK, 2007.

68. Denoël, J.F. Fire Safety and Concrete Structures; FEBELCEM: Brussels, Belgium, 2007.

69. Wang, J. Vertical Movement Monitoring in Six-Storey Wood-Frame Building in British Columbia; FPInnovations: Pointe-Claire, QC, USA, 2016.

70. Bueno, A.M.; Xavier, A.A.; Broday, E.E. Evaluating the Connection between Thermal Comfort and Productivity in Buildings: A Systematic Literature Review. Buildings 2021, 11, 244. [CrossRef]

71. Atanasiu, B.; Despret, C.; Economidou, M.; Maio, J.; Nolte, I.; Rapf, O. (Eds.) Europe's Buildings Under the Microscope: A Country-By-Country Review of the Energy Performance of Buildings; Buildings Performance Institute Europe: Brussels, Belgium, 2011.

72. Scott, L.; Towey, B. Room for Improvement: Air Tightness in Timber Frame Construction. In ICSDEC 2012: Developing the Frontier of Sustainable Design, Engineering, and Construction, Proceedings of the 2012 International Conference on Sustainable Design, Engineering, and Construction, Fort Worth, TX, USA, 7-9 November 2012; Chong, W.K.O., Gong, J., Chang, J., Siddiqui, M.K., Eds.; ASCE: Reston, VA, USA, 2013.

73. Lee, D.S.; Naboni, E. Exploring the relationship between structurally defined geometrical parameters of reinforced concrete beams and the thermal comfort on indoor environment. Procedia Eng. 2017, 180, 741-750. [CrossRef]

74. Kuczyński, T.; Staszczuk, A. Experimental study of the influence of thermal mass on thermal comfort and cooling energy demand in residential buildings. Energy 2020, 195, 116984. [CrossRef]

75. Kaynakli, O.; Yigit, A. Effects of radiant temperature on thermal comfort. Build. Environ. 2007, 42, 3210-3220. [CrossRef]

76. Padfield, T.; Jansen, L.A. Humidity buffering of building interiors by absorbent materials. In Proceedings of the 9th Nordic Symposium on Building Physics, Tampere, Finland, 29 May-2 June 2011; Tampere University of Technology: Tampere, Finland, 2011; pp. 475-482.

77. Berge, B. The Ecology of Building Materials; Elsevier: Oxford, UK, 2000.

78. Straube, J.; Smegal, J. Building America Special Research Project: High-R Walls Case Study Analysis; Building Science Press: Somerville, MA, USA, 2009.

79. Wyon, D.P. The effects of indoor air quality on performance and productivity. Indoor Air. 2004, 14, 92-101. [CrossRef]

80. Straube, J.F.; Acharya, V. Indoor Air Quality, Healthy Buildings, and Breathing Walls. In Proceedings of the 1998 Excellence in Building Conference, Washington, DC, USA, 28-31 October 1998.

81. Fantuccia, S.; Isaia, F.; Serra, V.; Dutto, M. Insulating coat to prevent mold growth in thermal bridges. Energy Procedia 2017, 134, 414-422. [CrossRef]

82. Morgan, C. Design and Detailing for Airtightness-SEDA Design Guides for Scotland: No. 2. 2006. Available online: https: / / cupdf.com/document/design-and-detailing-for-airtightness-and-detailing-for-airtightness-seda-design.html (accessed on 22 December 2020).

83. Saber, H.; Lacasse, M.A.; Ganapathy, G.; Plescia, S.; Parekh, A. Risk of condensation and mold growth in highly insulated wood-frame walls. In Proceedings of the Thirteenth International Conference on Thermal Performance of the Exterior Envelopes of Whole Buildings, Clearwater Beach, FL, USA, 4-8 December 2016.

84. Mannan, M.; Al-Ghamdi, S.G. Indoor Air Quality in Buildings: A Comprehensive Review on the Factors Influencing Air Pollution in Residential and Commercial Structure. Int. J. Environ. Res. Public Health. 2021, 18, 3276. [CrossRef]

85. World Health Organization. Regional Office for Europe. WHO Guidelines for Indoor Air Quality: Selected Pollutants; WHO Regional Office for Europe: Copenhagen, Denmark, 2010.

86. EN 16516:2019. Construction Products_Assessment of Release of Dangerous Substances_Determination of Emissions into Indoor Air; European Committee for Standardization: Brussels, Belgium, 2019.

87. Vardaxis, N.G.; Bard, D.; Waye, K.P. Review of acoustic comfort evaluation in dwellings—Part I: Associations of acoustic field data to subjective responses from building surveys. Build. Acoust. 2018, 25, 151-170. [CrossRef]

88. Torresin, S.; Albatici, R.; Aletta, F.; Babich, F.; Kang, J. Assessment methods and factors determining positive indoor soundscapes in residential buildings: A systematic review. Sustainability 2019, 11, 5290. [CrossRef]

89. ISO 12354-1:2017. Building acoustics-Estimation of Acoustic Performance of Buildings from the Performance of Elements-Part 1: Airborne Sound Insulation between Rooms; International Organization for Standardization: Geneva, Switzerland, 2017.

90. ISO 12354-2:2017. Building Acoustics-Estimation of Acoustic Performance of Buildings from the Performance of Elements-Part 2: Impact Sound Insulation Between Rooms; International Organization for Standardization: Geneva, Switzerland, 2017.

91. Mijić, M. Akustika u arhitekturi; Nauka: Belgrade, Serbia, 2001. 
92. Wang, D.; Xie, S.; Feng, Z.; Liu, X.; Li, Y. Investigating the Effect of Dimension Parameters on Sound Transmission Losses in Nomex Honeycomb Sandwich. Appl. Sci. 2020, 10, 3109. [CrossRef]

93. Di Bella, A.; Granzotto, N.; Barbaresi, L. Analysis of acoustic behaviour of bare CLT floors for the evaluation of impact sound insulation improvement. In Meetings on Acoustics, Proceedings of the 22nd International Congress on Acoustics, Buenos Aires, Argentina, 5-9 September 2016; Acoustical Society of America: Melville, NY, USA, 2017.

94. Schiavi, A. Improvement of Impact Sound Insulation: A Constitutive Model for Floating Floors. Appl. Acoust. 2018, 129, 64-71. [CrossRef]

95. Jayalath, A.; Navaratnam, S.; Gunawardena, T.; Mendis, P.; Aye, L. Airborne and impact sound performance of modern lightweight timber buildings in the Australian construction industry. Case Stud. Constr. Mater. 2021, 15, e00632. [CrossRef]

96. Badino, E.; Shtrepi, L.; Astolf, A. Acoustic Performance-Based Design: A Brief Overview of the Opportunities and Limits in Current Practice. Acoustics 2020, 2, 246-278. [CrossRef]

97. Howarth, P.A. Assessment of the visual environment. In Evaluation of Human Work, 3rd ed.; Wilson, J.R., Corlett, N., Eds.; Taylor \& Francis Group: Boca Raton, FL, US, 2005; pp. 663-692.

98. Ozorhon, I.F.; Uraz, T. Natural light as a determinant of the identity of architectural space. J. Archit. Urban. 2014, 38, 107-119. [CrossRef]

99. Vanhoutteghem, L.; Skarning, G.C.J.; Hviid, C.A.; Svendsen, S. Impact of façade window design on energy, daylighting and thermal comfort in nearly zero-energy houses. Energy Build. 2015, 102, 149-156. [CrossRef]

100. Mangkuto, R.A.; Rohmah, M.; Asri, A.D. Design optimisation for window size, orientation, and wall reflectance with regard to various daylight metrics and lighting energy demand: A case study of buildings in the tropics. Appl. Energy 2016, 164, 211-219. [CrossRef]

101. Makaremi, N.; Schiavoni, S.; Pisello, A.L. Effects of surface reflectance and lighting design strategies on energy consumption and visual comfort. Indoor Built Environ. 2018, 28, 552-563. [CrossRef]

102. Singh, S.; Kapoor, N. Health Implications of Electromagnetic Fields, Mechanisms of Action, and Research Needs. Adv. Biol. 2014, 2014, 198609. [CrossRef]

103. SAFETY CODE 6. Limits of Human Exposure to Radiofrequency Electromagnetic Energy in the Frequency Range from $3 \mathrm{kHz}$ to $300 \mathrm{GHz}$; Health Canada: Ottawa, ON, Canada, 2015.

104. Choroszucho, A.; Stankiewicz, J.M. Using FDTD method to the analysis of electric field intensity inside complex building constructions. Electr. Eng. 2019, 97, 39-48. [CrossRef]

105. Vizi, G.N.; Vandenbosch, G.A.E. Building materials and electromagnetic radiation: The role of material and shape. J. Build. Eng. 2016, 5, 96-103. [CrossRef]

106. Riratanaphong, C.; Voordt, T. Measuring the added value of workplace change: Performance measurement in theory and practice. Facilities 2015, 33, 773-792. [CrossRef]

107. Larssen, A.K.; Bjørberg, S. User demands for functionality and adaptability of buildings-A model and tool for evaluation of buildings. In Proceedings of the CIBW70 2004 Hong Kong International Symposium, Hong Kong, 7-8 December 2004; The Hong Kong Polytechnic University: Hong Kong, 2004; pp. 167-176.

108. Hillier, B.; Hanson, J. The Social Logic of Space; Cambridge University Press: Cambridge, UK, 1989.

109. Alexander, C.; Ishikawa, S.; Silverstein, M. A Pattern Language: Towns, Buildings, Construction; Oxford University Press: New York, NY, USA, 1977.

110. Kiesler, F. On correalism and biotechnique: A definition and test of a new approach to building design. Archit. Rec. 1993, 86, 60-75.

111. Kamara, J.M.; Heidrich, O.; Tafaro, V.E.; Maltese, S.; Dejaco, M.C.; Re Cecconi, F. Change Factors and the Adaptability of Buildings. Sustainability 2020, 12, 6585. [CrossRef]

112. Askar, R.; Bragança, L.; Gervásio, H. Adaptability of Buildings: A Critical Review on the Concept Evolution. Appl. Sci. 2021, 11, 4483. [CrossRef]

113. Jiménez-Pulido, C.; Jiménez-Rivero, A.; García-Navarro, J. Strategies to Promote Deep Renovation in Existing Buildings. In Rethinking Sustainability Towards a Regenerative Economy; Andreucci, M.B., Marvuglia, A., Baltov, M., Hansen, P., Eds.; Springer Nature: Cham, Switzerland, 2021; pp. 377-394.

114. Beadle, K.; Gibb, A.; Austin, S.; Fuster, A.; Madden, P. Adaptable futures: Sustainable aspects of adaptable buildings. In Proceedings of the 24th Annual ARCOM Conference, Cardiff, UK, 1-3 September 2008.

115. Davison, N.; Gibb, A.G.; Austin, S.A.; Goodier, C.I. The multispace: Adaptable building concept and its extension into mass customization. In Proceedings of the International Conference On Adaptable Building Structures, Eindhoven, The Netherlands, 3-5 July 2006.

116. Saari, A.; Heikkila, P. Building flexibility management. Open Constr. Build. Technol. J. 2008, 2, 239-242. [CrossRef]

117. Khanh, B.N. Developing a Framework for Assessing Sustainability of Tall Building Projects. Ph.D. Thesis, The University of Sheffield, Sheffield, UK, 2012.

118. Ross, B.E.; Chen, D.A.; Conejos, S.; Khademi, A. Enabling Adaptable Buildings: Results of a Preliminary Expert Survey. Procedia Eng. 2015, 145, 420-427. [CrossRef]

119. Gorgolewski, M.; Straka, V.; Edmonds, J.; Sergio, C. Facilitating Greater Reuse and Recycling of Structural Steel in the Construction and Demolition Process; Ryerson University: Toronto, ON, Canada, 2006. 
120. Russell, P.; Moffatt, S. Assessing Buildings for Adaptability—Annex 31-Energy-Related Environmental Impact of Buildings; International Energy Agency: Paris, France, 2001.

121. Pukītea, I.; Geipeleb, I. Different Approaches to Building Management and Maintenance Meaning Explanation. Procedia Eng. 2017, 172, 905-912. [CrossRef]

122. Islam, R.; Nazifa, T.H.; Mohammed, S.F.; Zishan, M.A.; Yusof, Z.M.; Mong, S.G. Impacts of design deficiencies on maintenance cost of high-rise residential buildings and mitigation measures. J. Build. Eng. 2021, 39, 102215. [CrossRef]

123. Alexander, M.G. Service life design and modelling of concrete structures-Background, developments, and implementation. Rev. ALCONPAT 2018, 8, 224-245. [CrossRef]

124. Teplý, B.; Podrouzek, J. Service life, reliability and their role in the life cycle analysis of concrete structures. Adv. Environ. Res. 2017, 55, 47-63.

125. Korytarova, J.; Hromádka, V. Building life cycle economic impacts. In Proceedings of the International Conference on Management and Service Science, Wuhan, China, 24-26 August 2010.

126. Narasimhan, H.; Chew, M.Y.L. Integration of durability with structural design: An optimal life cycle cost based design procedure for reinforced concrete structures. Constr. Build. Mater. 2009, 23, 918-929. [CrossRef]

127. Kanniyapanad, G.; Nesanb, L.J.; Mohammad, I.S.; Keatd, T.S.; Ponniahe, V. Selection criteria of building material for optimising maintainability. Constr. Build. Mater. 2019, 221, 651-660. [CrossRef]

128. Ishak, H.; Chohan, A.H.; Ramly, A. Implications of design deficiency on building maintenance at post-occupational stage. J. Build. Apprais. 2007, 3, 115-124. [CrossRef]

129. Schultmann, F.; Sunke, N.; Krüger, P. Global performance assessment of buildings: A critical discussion of its meaningfulness. In Proceedings of the 3rd CIB International conference on Smart and Sustainable Built Environments, Delft, The Netherlands, 15-19 June 2009.

130. Grobman, J.Y.; Yezioro, A.; Capeluto, G. Non-Linear Architectural Design Process. Int. J. Archit. Comput. 2010, 8, 41-54. [CrossRef]

131. Wolff, L.; Ehrström, P. Social Sustainability and Transformation in Higher Educational Settings: A Utopia or Possibility? Sustainability 2020, 12, 4176. [CrossRef] 